\title{
To Create Conceptual Concept So To Assist Farmer Economically
}

\author{
Shri. Krishna S. Vishwakarma ${ }^{1}$,Shri. R.S. Tamboli ${ }^{2}$, Mr. Aniket Kshirsagar $^{3}$, \\ Mr. Vicky Gedekar ${ }^{4}$ \\ ${ }^{1}$ Professor- Shri Datta Meghe Polytechnic, Wanadongri, Nagpur-441110 \\ ${ }^{2}$ Principal-Shri Datta Meghe Polytechnic, Wanadongri, Nagpur \\ ${ }^{3,4}$ Student- Shri Datta Meghe Polytechnic, Wanadongri, Nagpur
}

\begin{abstract}
In our country still our villager are struggling with short of money, living standard. Mainly our farmer does irrigation related activity when the season comes \& rest of the time they remain with no work this causes a biggest trouble to them because they uses money whatever they earn by selling their crops into their idle time i.e. off-season. ${ }^{l}$ Hence there living standard remain unchanged due to no moneysaving. Keeping this thing into mind we are trying to help farmer by giving them a chance of self-employment, so that, they can change their living standard to some extent. Hence we are focusing to develop a system/machine which can be run manually. The cost of the system or machine will try to keep very minimum, so that the farmer can purchase it or taken it on rent. The objective of our machine is to utilize mainly agriculture based product which is available at very low price along with some additives. Through this project the farmer can produce a daily consumable product which would be so called as "AGRO AGARBATTI".
\end{abstract}

Keywords: Push disk design, Mixing chamber, Function, Hopper, Critical data, Agricultural waste, Home based machine, Dhoop - Agarbatti.

\section{Introduction}

The main concept of the project is to help farmer by utilizing their remaining time for satisfying themselves about their income. Normally farmer thinks that they should have more money than that of present. They face various problem in their life like to provide education to their children, to buy seeds for farming, to buy equipment etc. In villages wastage like cow dunk, wooden powder are probably observe to used that raw material for their benefits is our Moto. Now a day's wastage is only used as a fertilizers but we have different concept to used wastage and helps to farmer. We used raw material which is freely available in villages and those wastage which they are not using in their life to make new product which should be called as Natural Dhoop Agarbatti in which we mix the various raw material like cow dunk, wooden powder, paper pulp,dink,luban, camphor etc to make Dhoop Agarbatti. by launching this new product in market as side business they can improve their lifestyle from this business income.

\section{DATACOLLECTION THROUGH LITERATURE SURVEY}

\section{1) CONCEPT AVAILABLE IN MARKET}

In the market Dhoop product is easily available. The current Dhoop products and machines are shown below

Dhup Products Available in Market

\begin{tabular}{|c|c|c|c|c|c|}
\hline$S . \mathrm{N}$ & Brand of Product & $\begin{array}{c}\text { Size } \mathrm{d}^{*} \mid \\
\mathrm{mm}^{*} \text { inch }\end{array}$ & Wt (gm) & $\begin{array}{l}\text { No.of } \\
\text { Sticks }\end{array}$ & $\begin{array}{l}\text { Price } \\
\text { Rs. }\end{array}$ \\
\hline 1 & Shri-Hari Agarbatti & $8 * 3$ & 100 & 12 & 25 \\
\hline 2 & Arsi Agarbatti & $8 * 4$ & 100 & 15 & 30 \\
\hline 3 & Dwarikamai Aggarbati & $8 * 5$ & 100 & 10 & 20 \\
\hline 4 & Agarwal Dhoop Company & $8 * 6$ & 100 & 20 & 40 \\
\hline 5 & Nirmal Sugandh Udyog & $8 * 7$ & 100 & 30 & 30 \\
\hline
\end{tabular}


The above shows table shows the Dhoop product brands which are available in the market. The tables contain its size and price also.

1.1) TYPES OF MACHINE AVAILABLE ALONG WITH IT'S PRICE \& CAPACITY

Machine Related Available Data

\begin{tabular}{|l|l|l|c|c|l|c|}
\hline S.N & Machine Available & $\begin{array}{c}\text { Machine } \\
\text { Wt (kg) }\end{array}$ & $\begin{array}{c}\text { Machine } \\
\text { Product Size d/I } \\
(\mathrm{mm})\end{array}$ & $\begin{array}{l}\text { Power } \\
\mathrm{Hp}\end{array}$ & Capacity/ hr & Price \\
\hline 1 & $\begin{array}{l}\text { Auto dhoopbatti } \\
\text { making machine }\end{array}$ & 175 & $6,8,10 / 3^{\prime \prime}, 4^{\prime \prime}, 2^{\prime \prime}$ & 2 & $\begin{array}{l}13- \\
15 \mathrm{~kg} / 24 \mathrm{hr}\end{array}$ & $112000 / \cdot$ \\
\hline 2 & $\begin{array}{l}\text { High speed agarbatti } \\
\text { making machine }\end{array}$ & 50 & $3,5,8 / 1^{\prime \prime}, 2^{\prime \prime}, 1.5^{\prime \prime}$ & 5 & $\begin{array}{l}12 \cdot \\
15 \mathrm{~kg} / 10 \mathrm{hr}\end{array}$ & $140000 / \cdot$ \\
\hline 3 & $\begin{array}{l}\text { Incence powder } \\
\text { mixing machine }\end{array}$ & 50 & $6,8,10 / 3^{\prime \prime}, 4^{\prime \prime}, 2^{\prime}$ & 0.5 & $15-20 \mathrm{~kg} / 24$ & $84000 / \cdot$ \\
\hline & & & & & & \\
\hline
\end{tabular}

In the above table shows machine related data is shown. In this table machine weight, power required, size, price and capacity is available.

\section{2) CONTENTS AVAILABLE IN MARKET}

\begin{tabular}{|c|c|c|c|c|}
\hline \multicolumn{5}{|c|}{ Ingredients of Market Product } \\
\hline S.N & Ingredients & $\begin{array}{c}\text { Hydro } \\
\text { carbon } \\
\text { HC } \\
(\mathrm{ppm})\end{array}$ & $\begin{array}{c}\text { Co2 } \\
\text { Level \% }\end{array}$ & $\begin{array}{c}\text { Price Rs/ } \\
\mathrm{Kg}\end{array}$ \\
\hline 1 & $\begin{array}{l}\text { latex liquid } \\
\text { chemical }\end{array}$ & 898 & 14.5 & $120.5 /-$ \\
\hline 2 & $\begin{array}{l}\text { Burning } \\
\text { Powder - } \\
\text { Charcoal }\end{array}$ & 1064 & 12.08 & $46.97 /-$ \\
\hline 3 & Khasa Powder & 377 & 2.3 & $220 /-$ \\
\hline 4 & Burn Oil & 1050 & 20 & 70/- \\
\hline 5 & Wood Powder & 230 & 2.8 & $5.00 /-$ \\
\hline 6 & Cow Dung & 202 & 3.5 & $3 /-$ \\
\hline 7 & Paper Pulp & 120 & 6.9 & $10 /-$ \\
\hline 8 & Kapur & 171 & 4.15 & $440 /-$ \\
\hline 9 & Luban & 162 & 3.75 & $230 /-$ \\
\hline
\end{tabular}

In the above mention table ingredients required to dhoop agarbatti production is shown.the basic elements with its price and $\mathrm{Co}_{2}$ level. Besically all this are useful for production purpose of dhoop agarbatti.

\section{3) MATERIAL DATA SHEET}

This sheet contains the information about the material which is used to fabricate our dhoopAgarbatti machine. It also contains the material required and its price.

\begin{tabular}{|c|c|c|c|c|c|c|}
\hline \multicolumn{7}{|c|}{ Material Data } \\
\hline $\begin{array}{l}\text { Sr. } \\
\text { no }\end{array}$ & Materials & Size & aty. & $\mathrm{kg}$ & $\begin{array}{l}\text { Price } \\
\text { Rs. }\end{array}$ & \begin{tabular}{|l|} 
Total \\
Rs.
\end{tabular} \\
\hline 1 & M.SChanel & $100^{*} 50 \mathrm{~mm}$ & $2 \mathrm{~m}$ & 18.56 & $206 /-$ & 1350 \\
\hline 2 & M.S Sheet & 16 Gauge & $2.5 \mathrm{~m}$ & 31.6 & $75 /-$ & 2370 \\
\hline 3 & Round Bar & Dia.25 mm & $1.8 \mathrm{~m}$ & 8.9 & $127 /-$ & 750 \\
\hline 4 & \begin{tabular}{|l|} 
M.S Flat \\
\end{tabular} & $40^{*} 5 \mathrm{~mm}$ & $3 m$ & 10.84 & $61 /-$ & 600 \\
\hline 5 & General Bearing & Dia.25 mm & 3 nos & & $300 \%$ & 900 \\
\hline 6 & Bevel Gear & Dia. $25 \mathrm{~mm}$ & 2 nos & & $1000 /-$ & 2000 \\
\hline 7 & \begin{tabular}{|l} 
G.I Ball Valve \\
\end{tabular} & \begin{tabular}{|l|} 
Dia.1" \\
\end{tabular} & 2 nos & & $400 \%$ & 800 \\
\hline 8 & \begin{tabular}{|l|} 
G.I reducer \\
\end{tabular} & Dia.1" & 2 nos & & $22.5 /-$ & 45 \\
\hline 9 & G.I Nipple & Dia.1" & 2 nos & & $16 /-$ & 32 \\
\hline 10 & Bolt & $1 / 2^{n *} 1 / 2^{n}$ & & 2 & $80 \%$ & 160 \\
\hline 11 & Bush & Dia. $26 \mathrm{~mm}$ & 2 nos & & $100 \%$ & 200 \\
\hline 12 & Angle(M.S) & $\begin{array}{l}40 * 40 * 5 \\
\mathrm{~mm}\end{array}$ & $9 \mathrm{~m}$ & 29.52 & $59.5 /-$ & 1755 \\
\hline 13 & Angle(M.S) & $\begin{array}{l}25 * 25 * 5 \\
\mathrm{~mm}\end{array}$ & $3 m$ & 6.56 & $60.5 /-$ & 160 \\
\hline 14 & Paint & $1 / 2 \operatorname{Ltr}^{*} 3$ & $\begin{array}{l}1.5 \\
\text { t.tr }\end{array}$ & 4 & $150 \%$ & 600 \\
\hline
\end{tabular}


4) FARMER RELATED DATA

Farmer Related Data

\begin{tabular}{|l|l|l|l|l|l|}
\hline S.N & Country & $\begin{array}{c}\text { \% of } \\
\text { Farmer } \\
\text { Country } \\
\text { wise }\end{array}$ & $\begin{array}{c}\text { Avg } \\
\text { Income/ } \\
\text { month }\end{array}$ & $\begin{array}{c}\text { Avg } \\
\text { Working } \\
\text { Days/ yr }\end{array}$ & \\
\hline 1 & India & 80 & 2115 & 209 & hand book of dairy farming \\
\hline 2 & Spain & 40 & 3660 & 288 & practical spanish for farmer \\
\hline 3 & Sri-Lanka & 80 & 4300 & 217 & the forest garden farms,hikkaduwa \\
\hline 4 & China & 30 & 4500 & 188 & chinese farmer painting \\
\hline
\end{tabular}

Above table contain the farmer related data in some different countries. Percentage of farmer in the country, average working days and income of farmers is also shown. This table is provides all data which is required to differentiate the farmers in countries.

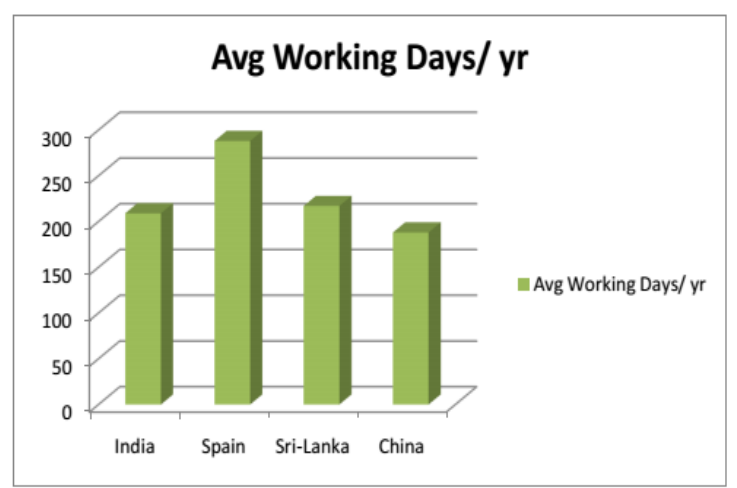

The percentage of farmers in the different countries in Asia is compared by following graph Average working days of farmers in different countries are shown in the following graph.

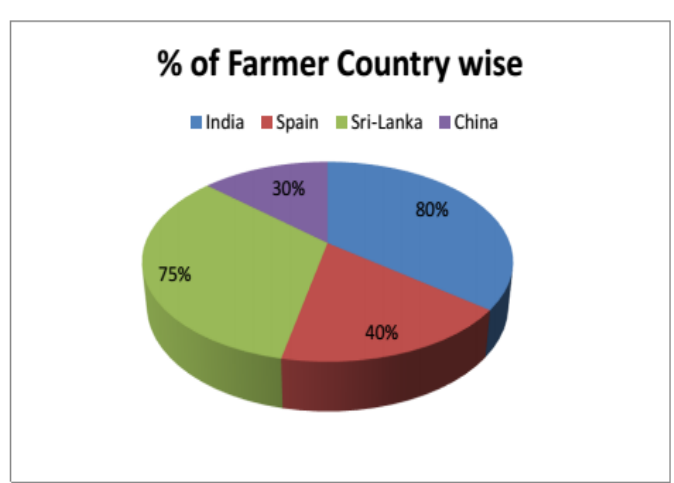

The following graph shows the average income of farmers in different countries. By compairing with other countries Chinies farmers earn high income.

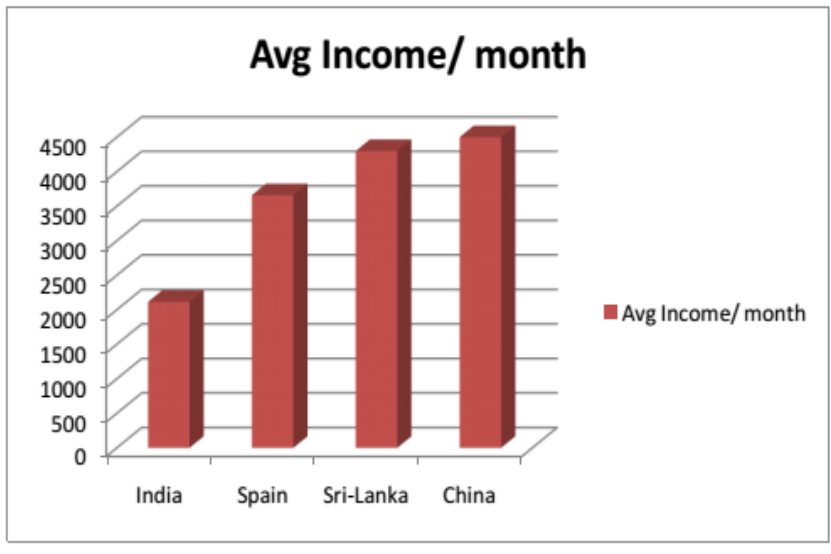




\section{PROBLEM STATEMENT}

\section{WHY WE WANT TO CHOOSE THIS TOPIC.}

If we look up at the nearby market, you will easily find numerous brand of Dhoop Agarbatti, but the important thing is how much it is safe to your health. The smoke comes out from the burning Dhoop Agarbatti contains various toxic gases like $\mathrm{Co}, \mathrm{Co}_{2}, \mathrm{Hc}$ etc. these gases produce bad effect on human eye \& health. Sometime these products contains some high amount of fragrances due to which after sometime of burning the Dhoop Agarbatti could cause human headache.

To reduce these effects we suggest a new concept of making Dhoop products which solve the purpose. By considering all problems we develop this concept and try to implement this in real life. The main aim of this concept is to make the human life more secured.

The other side of this project is to produce a machine which makes the Dhoop Agarbatti in a very low budget. The concept is to provide Agro Based Dhoop Agarbatti which may be produce by farmer at villages. The main motive of this topic selection is to boost and increase the economical condition of farmer in India because lots of farmer suicide cases is occurs due to their poor economical condition. To reduce the suicide cause we try to support them as providing part time work at their home from this project.

\section{ACTUAL CONDITIONS}

In our day to day life we face the problem of increasing price of all products. The life of common man is very hard to adjust all the things in minimum salary. If we consider the Dhoop product it also have high cost but the consumption of such product is daily at home. In the industry of Dhoop product the various types of machines are used. This machine consumed high amount of electricity. The cost of electricity in current condition is on the way of raising which also effect on the price of product. Also in factories there are three to four labor is required to handle the machine. This labor cost is also included in all type of Dhoop product that will be manufacture in the company therefore the cost of product is high. These are all the actual condition in the market for this product.

\section{FARMER RELATED PROBLEMS}

Now days the some Indian farmer is suffering from very poor economical condition because of fluctuation of rainfall in rainy season. Usually the farmer earns money in two times in a year because farmer produces two crops yearly. If the rain are not well than all the works of farmer gets failed and they lose their grains. They face the money problem in their life. Also they could not be able to gets two times food a day. Due to failure of products they even could not refund the loan of banks.

The children of the farmer are not able to study in the good school due to economical problem.

Farmer and their family spent valuable life in tension \& low economical condition only and because of that farmer get try to suicide due to such bad problems of their life.

\section{PROBLEM SELECTION FARMER FINANCIAL SUPPORT}

The condition of the farmer in India has not changed even after independence. They are still dependent on the rain for water And politicians for fixing remunerative prices. But, nothing going smoothly. Most of the farmers have burden of loans from banks and private money lenders, which they are not able to return and hence, have to take extreme step like suicide. The government is also not very worried about their condition. Therefore we provide the better solution for improve the economical condition of farmer. When the farmer used our concept they will definitely earn money daily. There is no requirement of higher expenditure also they used the raw material which is freely available I the villages for the production of agro-based Dhoop Agarbatti. hence by spending a small part of time farmer earn money through concept. And this is the best financial support for farmers to improve their economical condition.

\section{ROUTE CAUSES OF PROBLEM}

Indian farmers are poor because 1) they are not aware about market needs. 2) There valuable crop is not purchased at time plus they don't have personal storage facility. 3) They don't know alternate medium of income. 4) Intermediate parties manipulate them to sell their crop against any previous rate of loan. 5) Improper rain so they faced the shortage of water for crops.

\section{DEVELOPMENT OF OUR CONCEPT}

Design of "to create conceptual concept so to assist farmer economically" 


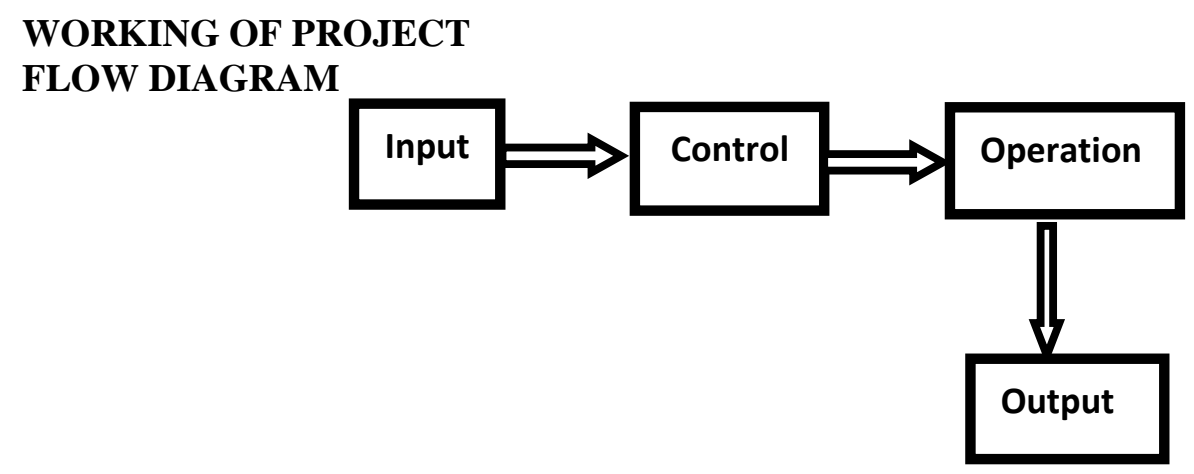

\section{DESCRIPTION}

We Inventing a new concept in which we design a machine that mixes the semi-solid material \& pushing it in downward direction with the help of tapered mixing blades which connected to a power transmission device. The machine consist of power transmission mechanism, hopper, mixing chamber, rotating plate consisting cone, material pusher, product outlet slurries, flow control vale etc. We provide rotating motion to the wheel by human effort. Wheel is connected to the bevel gear which convert the horizontal rotating motion to vertical motion. This vertical motion is given to the shaft( shaft is connected to bevel gear).we welded a tapered blades on vertical shaft which used to mix the raw material properly and we use Tapered blades for mixing and downward pressing of material at the end of shaft rotating plate is mounted. Bearing is to be placed between the plate and shaft for minimize the friction by which it give free rotating motion. On the rotating plate cones are fixed, which helps to received mixed material and passes to outlet slurries with some pressure .In this manner our machine works.

\section{CONCEPT PROJECT MACHINE}

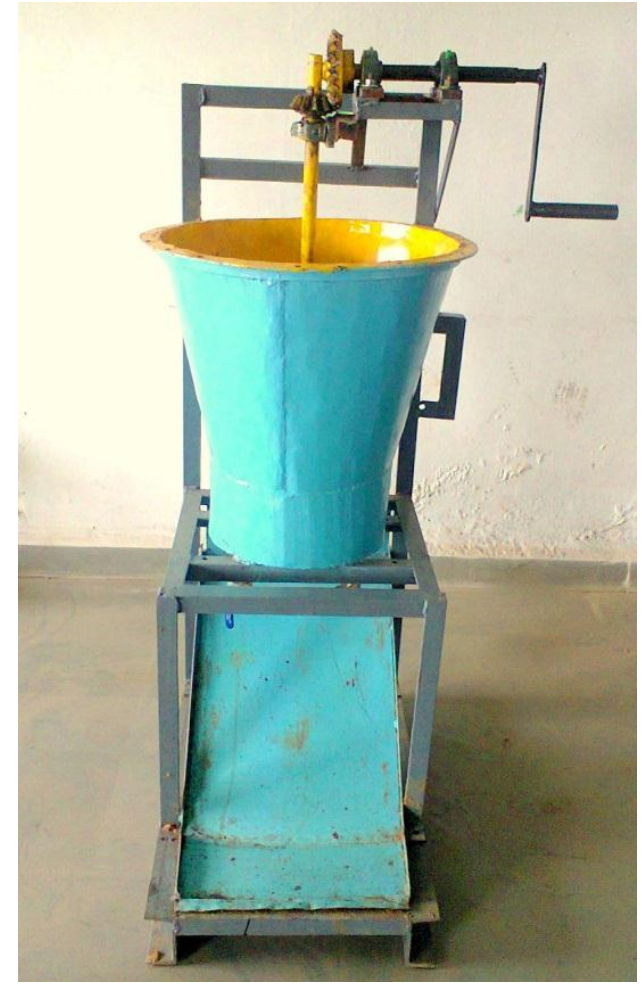

\section{EXPECTED RESULT WITH OUR CONCEPT}

FARMER BENEFIT:- As we also known that the Indian farmer are poor. They only do the farming at one time and cannot do another job. To see that problems we make this machine to provide the farmer some income resources. For this machine farmer can works after doing the farming work \& make Dhoop Agarbatti. In this machine the material used is easily available the village in very low cost. For this machine farmer definitely got the benefit in terms of money. 
SMOKE CONTAMINATION

\begin{tabular}{|r|l|r|r|r|r|r|}
\hline & & \multicolumn{5}{|c|}{ \% content } \\
\hline S.No & \multicolumn{1}{|l|}{ Particular } & \multicolumn{1}{l|}{ Co } & \multicolumn{1}{l|}{ HC } & \multicolumn{1}{l|}{ lO2 } & \multicolumn{1}{l|}{ Nox } \\
& & & & & & \\
\hline 1 & & & & & & \\
\hline 2 & Kharcol Powder & 1.27 & 1064 & 12.08 & 17.68 & 1.859 \\
\hline 3 & Latex & 0.28 & 77 & 2.3 & 16.32 & 1.64 \\
\hline 4 & & & & & & \\
\hline 5 & Cown Dunder & 0.01 & 898 & 14.5 & 32.5 & 4 \\
\hline 6 & Wood powder & 0.075 & 230 & 2.2 & 11.29 & 1.2 \\
\hline 7 & Paper Pulp & 0.029 & 120 & 3 & 15.72 & 1.338 \\
\hline 8 & Kapur & 0.98 & 171 & 2.5 & 15.5 & 2.232 \\
\hline 9 & Luban & 1.2 & 162 & 3.75 & 13.5 & 0.8 \\
\hline
\end{tabular}

Above table shows the smoke contamination of a particular. The table contain $\mathrm{Co}, \mathrm{Co}_{2}, \mathrm{Nox}, \mathrm{Hc}, \mathrm{O}_{2}$ percentage in a specific particular.

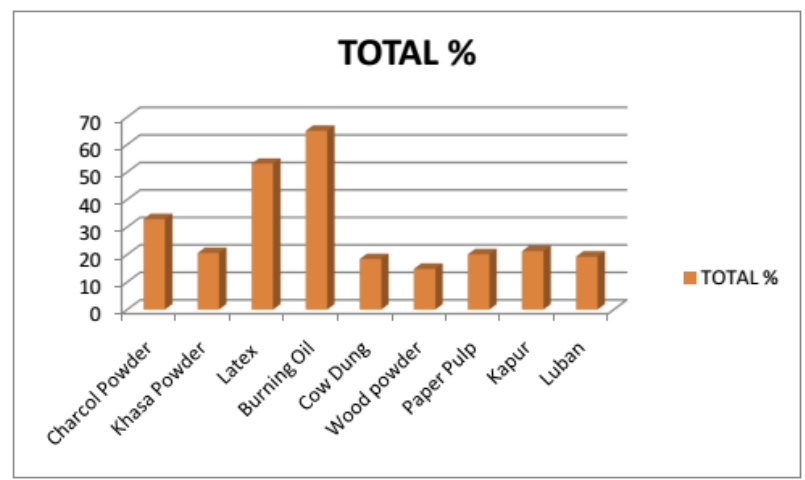

\section{CONTAINS OF PARTICULAR IN PRODUCT}

The following table shows the ingredients and its ratio in our dhoop product. These percentages are specially decided by getting the trial on the Dhoop Agarbatti machine.

\begin{tabular}{|l|l|}
\hline \multicolumn{2}{|c|}{ Ingredients } \\
\hline Particular & $\begin{array}{c}\text { contains } \\
\%\end{array}$ \\
\hline Wood Powder & 25 \\
\hline Cow Dung & 60 \\
\hline Paper Pulp & 10 \\
\hline Kapur & 1 \\
\hline Luban & 4 \\
\hline
\end{tabular}


Also the graph shows the numeric value of the particular ingredients.

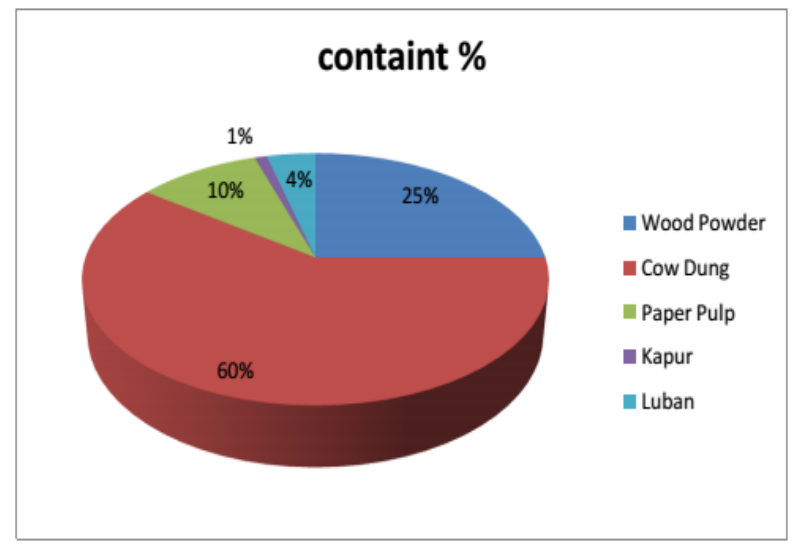

\section{COMPARISION OF OUR PRODUCT WITH CURRENT PRODUCT}

1) The table shows the smoke percentage of the current product. It contains the actual tested value of it.

\begin{tabular}{|r|c|r|}
\hline sr. no & Particular & Total(\%) \\
\hline 1 & $\begin{array}{c}\text { Charcoal } \\
\text { Powder }\end{array}$ & 32.889 \\
\hline 2 & $\begin{array}{c}\text { Khasa } \\
\text { Powder }\end{array}$ & 20.54 \\
\hline 3 & Letex & 53.01 \\
\hline 4 & $\begin{array}{c}\text { Burning } \\
\text { Oil }\end{array}$ & 65 \\
\hline 5 & Total & 171.439 \\
\hline
\end{tabular}

2) The table shows the smoke percentage of our product. It contain the actual tested value of it.

\begin{tabular}{|r|r|r|}
\hline Sr. No & Particular & Total(\%) \\
\hline 1 & Cow Dung & 18.374 \\
\hline 2 & $\begin{array}{c}\text { Wood } \\
\text { Powder }\end{array}$ & 14.765 \\
\hline 2 & $\begin{array}{c}\text { Paper } \\
\text { Pulp }\end{array}$ & 20.087 \\
\hline 2 & Kapur & 21.212 \\
\hline 2 & Lubhan & 19.25 \\
\hline 2 & Total & 93.688 \\
\hline
\end{tabular}

3) Total smoke contain in the product

\begin{tabular}{|l|c|}
\hline \multicolumn{2}{|c|}{ Smoke } \\
Contamination(\%) \\
\hline $\begin{array}{l}\text { Current } \\
\text { Product }\end{array}$ & 171.439 \\
\hline $\begin{array}{l}\text { Our } \\
\text { Product }\end{array}$ & 93.688 \\
\hline
\end{tabular}

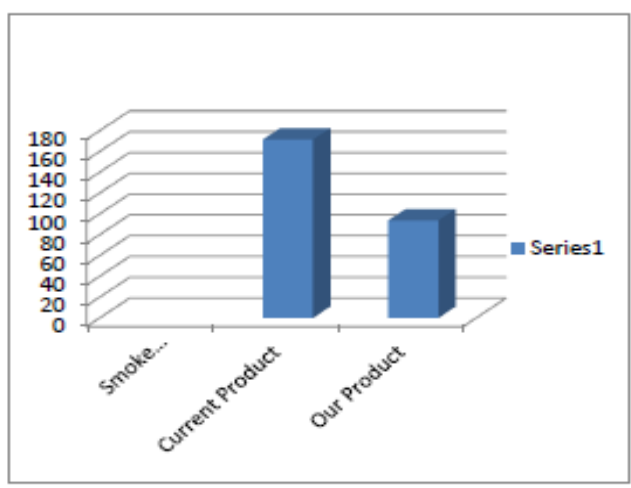


The above graph showing the comparison of current product with our product. After studying this graph we conclude that our product is less harmful to human being and also smoke contains is very less as compared to other.

The raw material required to make this product is also very cheaper.

\section{DAILY INCOME}

By using this machine farmer daily make dhoopAgarbatti\& sales it

$\&$ get some income every day. The does not required any electrical, labor or other cost. The daily income is depend income is depend on amount of dhoopAgarbatti he make per day.

\section{SUMMARY}

Special thanks to guide, college, ME-dept., group members to help to develop this concept by spending our valuable time. The aim of this concept is to improve the economical Condition of farmers. This concept contains Problems statements related to farmers, actual condition, farmer financial support, causes of problems, and the solution over it is included.

\section{Reference}

[1]. The hand book of dairy farming in India, Engineers India Research Institute publication, 2005, Vol-2

[2]. The journal of Chinese farmer painting of China, by DiaterWanazura, Chines Art publication, June 2005, Vol-1

[3]. Book of Design of machine element by VinodThombrePatil, Nirali publication, June 2013.

[4]. The book of Advance manufacturing processes by P.K.Ambadekar, S.T.Ghan, and D.M.Dharmadhikari, publication, June 2013.

\section{AUTHORS}

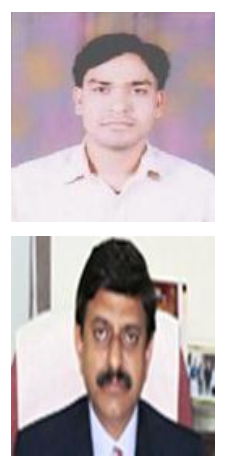

Shri. Krishna S. Vishwakarma

Professor, shri data meghe polytechnic

Wanadongri, Nagpur

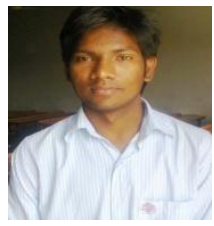

Shri. R.S. Tamboli

Principle, shri datta meghe polytechnic

Wanadongri, Nagpur

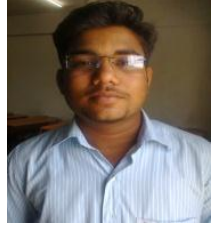

Mr. Vicky Gedekar

Student, shri datta meghe polytechnic

Wanadongri, Nagpur 